\title{
НАРАТИВНО-МЕНТАТИВНІ ОСОБЛИВОСТІ ЕСЕ ЕПІСТОЛЯРНОГО ТИПУ В СУЧАСНІЙ УКРАЇНСЬКІЙ ЛІТЕРАТУРІ (Листи з Києва С. ПавЛичко)
}

\author{
ТЕТЯНА ШЕВЧЕНКО \\ Одеський національний університет імені I. I. Мечникова, Одеса - Україна \\ shtn75@ukr.net; ORCID: 0000-0002-8118-9663 \\ NARRACYJNO-MENTATYWNE CECHY ESEJU EPISTOLARNEGO \\ WE WSPÓŁCZESNEJ LITERATURZE UKRAIŃSKIEJ (Листи з Києва S. Pawłyczko)
}

TETIANA SZEWCZENKO

Odeski Uniwersytet Narodowy imienia Ilji Miecznikowa, Odessa — Ukraina

STRESZCZENIE. Artykuł traktuje o narracyjno-mentatywnym charakterze Listów z Kijowa Salomei Pawłyczko. Wykazano, iż w esejach-listach tomu narracja przeradza się w rozważania, podobnie jak narrator — w myśliciela. Narratyw i mentatyw stają się podstawowymi składnikami struktury tekstu, uzupełniając się nawzajem i tym samym tworząc całość. Taka struktura otwiera nowe możliwości przed esejem z punktu widzenia strategii komunikacyjnych w twórczości pisarzy.

Słowa kluczowe: cechy narracyjno-mentatywne, esej epistolarny, narrator, charakter epistolarny, współczesna literatura ukraińska.

\author{
NARRATIVE AND MENTATIVE FEATURES \\ OF EPISTOLARY TYPE IN MODERN UKRAINIAN LITERATURE \\ (S. Pavlychko’s Листи з Києва) \\ TETIANA SHEVCHENKO \\ Odesa I. I. Mechnikov National University, Odesa - Ukraine
}

\begin{abstract}
The article focuses on the narrative and mentative nature of S. Pavlychko's Letters from Kyiv. It has been proved that the essay-letters in this collection grow into a thinking process and the narrator becomes a thinker. The narrative and mentative features become each other's important components creating a full integrity. Such structure opens new opportunities for the essays as a discursive practice from the point of view of the communicative strategies in the works of the writers.

Key words: narrative and mentative features, essay-letter, narrator, epistolary type, modern Ukrainian literature.

\footnotetext{
7 ерегляд традиційних концепцій і поява нових підходів до аналізу художнього твору - наочна ознака літературознавства й критики кінця XX - поч. XXI ст. Особливої актуальності в ньому набуває переакцентуація здобутку письменницької есеїстики, напрочуд продуктивної останнім часом у сучасній українській літературі. Дослідження творчості окремих майстрів художньо довершеного інтелектуального письма, визначення його місця в історії української культури, вироблення загальної концепції літератури періоду Незалежності - це ті наукові вектори, що є визначальними для філологічної науки сучасності.
} 
Дискурсивна практика есе в сучасній українській літературі репрезентована численними видами й варіаціями. Серед есеїв варто виділити твори мемуарного типу (Роман Іваничук Серед повені книг. Записки бібліофіла, Василь Махно Котилася торба, Віктор Неборак Введення у „Бу-Ба-Бу”, Колишній / інший), щоденникового (Галина Пагутяк Кожен день - iнший, Свген Баран Недописана книга), епістолярного (Соломія Павличко Листи з Києва, Віталій Коротич Цілком особисто, Оксана Забужко В. Шевельов: Вибране листування на тлі доби 1992-2002, Анатолій Дністровий Письмо з околиці) тощо. Так, зі сторінок більшості збірок останньої групи постає інтелектуальна оцінка сучасності й історії крізь призму особистої обсервації й осмислення. Листи, що спершу виконували функцію приватної та інтимної комунікації, у надрукованому вигляді впорядкованої книги, зітканої з фрагментів особистісної оцінки довкілля й рефлексії, набувають нових ознак, насамперед властивих есеїстичним практикам, адже в них наратор і мислитель стають єдиним цілим, репрезентуючи багатопланову і складно організовану творчу субстанцію, наділену універсальним статусом. У листах-есеях за допомогою засобів інтимізації оголюється мисленнєвий процес, цікавий своєю безпосередністю й рефлексивною розкутістю, висловлюються індивідуальні думки й враження, обговорюється та чи та тема - культурологічна, філософська, літературознавча, політична, що, проте, не претендує на вичерпність і остаточність. Словом, лист залишається тільки формою, наповненою есеїстичним змістом.

Лист як есе відриває нові можливості й наративного дискурсу: інтимізація, відвертість, комунікативна стратегія ведення постійного діалогу з адресатом створюють унікальну платформу для змістовного домінування ментативу на основі наративу. Він, власне, концептуалізує референтний зміст есе.

Саме такі можливості наративу й ментативу з його різноманітними комунікативними стратегіями розвитку та оформлення думки й засобами текстотворення відкриває збірка Листи з Києва С. Павличко, що вперше вийшла 2000 р. у видавництві “Основи” (перед цим 1992 р. побачила світ англійською мовою в США і одразу була включена до університетських курсів "радянських студій" Америки й Канади, адже в ній було багато цінної інформації, що надто резонувала 3 офіційними джерелами про події кінця 80-х - поч. 90-х рр. ХХ ст. в Україні). Листи вирізняються гостротою оцінок подій і фактів бурхливої епохи здобування незалежності, побачених і осмислених С. Павличко, яка була безпосереднім її учасником, а також мисленнєвою настановою. Відчуття, переживання, емоції й настрої передають стан душі адресантки, різноаспектність мисленнєвих процесів у складних екстремальних умовах буття.

Документальні факти, пропущені крізь свідомість рядками в записах, що передавалися через друзів у Канаду, навіть не поштою, формували громадянську й національну свідомість адресантки, тренували спостережливість і вправність художника й науковця, стали основою творчих задумів, зрештою, явили митця нової генерації - обсерватора, що ставав мислителем. Оцінюючи унікальність Листів з Києва (збірка, що складається з творів, а priori не призначених для оприлюднення, у надрукованому вигляді стала “літописом самовидця”), О. Забужко назвала ііі “єдиним живим документом тої епохи”, “голосом інтелектуальної України”, а працю авторки - “інтелектуальною чесністю”, “колосальним трудом душі”'. Ця збірка, як не дивно, ще не була об'єктом грунтовного

\footnotetext{
${ }^{1}$ О. Забужко, Репортаж з 2000-го року, Київ 2000, с. 72-73.
} 
наукового осмислення, зокрема в аспекті наративно-ментативної природи, тож цьому аспекту варто присвятити окреме дослідження.

Отже, тексти, написані С. Павличко, балансують між епістолою, хронописом і есеєм. У них скрупульозно й методично омовлюються події останніх років існування СРСР в українському розрізі з різним ступенем інтенсивності. Цим подіям дається оцінка, що переростає в рефлексії різного характеру. Над усім цим стає мислитель-інтелігент, який відбирає для осягнення тільки те, що цінне для тих часів і подій. Враження про те, що адресант хоче розповісти про все й одразу, не виникає. Системність есеїв у збірці створюється парадоксальністю суб'єктно-об'єктних відносин у структурі тексту: адресант звертається й до Богдана Кравченка - професора з Канади, який попросив повідомляти про те, що відбувається в Україні 1990-1991 р.p., і до написаного в попередніх листах, і до власних міркувань, викладених у дотеперішніх епістоляріях.

Листи, що вийшли друком у видавництві “Основи”, відкрили нові ознаки епістолярного жанру й есеїстичного твору водночас. Відредаговані текстиепістоли (імовірно, надто особисті моменти вилучено перед оприлюдненням), укладені упорядником Богданом Кравченком, оформлені в окрему збірку (із передмовою, примітками, автобіографічною довідкою), вочевидь, явили твори іншого штибу: латентні ознаки художності й есеїстичності, закладені в них із самого початку, виходять на поверхню і стають першорядними, в окремих випадках поступаючись навіть оповідному началу. Якщо в першій половині листів (1990) більшою мірою адресантка робила акцент на самих подіях в Україні, то в другій частині (1991) наративний складник поступається ментативному, адже міркування, оцінювання, зокрема й превентивні, навіть візуально почали займати більше місця в листах. “Друге” життя листів несподівано засвідчило зміни їхньої дискурсивної організації. Насамперед відбулося зміщення референції в бік ментальних подій: у листах стало цікаво читати не тільки про те, що сталося в Україні в інтерпретації авторки, а й те, як ті чи ті події змінили іії власну свідомість. Це, відповідно, зумовило й зміни креативного характеру: публіцистичний складник листів офарблюється засобами художнього слова, у листах з'являється чимало цікавих образів, відбувається інтерференція епістолярного, публіцистичного й художнього стилів з наданням переваги останньому чим далі, тим виразніше. Причому в цьому художньому стилі роздум стає першорядним, а розповідь і опис другорядними. А це, зрештою, змінило горизонти очікування читача (рецептивний аспект), якого спершу цікавили самі події й обставини написання й друку текстів, а потім несподівано відкриті нові можливості розповідача, що на його очах перетворюється із хронікера на мислителя. Отже, після виходу у світ київські листи втрачають ознаки приватного твору й набувають публічних рис. Читачеві стають цікавими не тільки факти, події, розповідні фрагменти, украплені в текст, а й хід міркувань, вектор мислетворення знакової мислячої особистості того часу в особі С. Павличко. Він - читач - звертає увагу й на фрагменти виключно художнього й есеїстичного характеру, привертають увагу переходи від власне оповідних компонентів до рефлексивних, цікавою стає сама інтерференція наративу й ментативу.

Усі листи, видані разом під однією обкладинкою, явили циклізований текст-оповідь-міркування, наділений високим ступенем когерентності. Так, кожна окрема епістола присвячена одній осмислювальній мікротемі. Однак у сукупності тексти сприймаються як одне монолітне полотно, зіткане з розповідей, що переростають у розмисли про сенс людського життя в добу змін, про 
страх, який щодня треба долати, про високе мистецтво, яке нетлінне, і про політику, яка проминальна, зрештою, про майбутнє, яке можна створити зараз. Хронологічні маркери листів, звернення до адресата, традиційні фігури початку й завершення листа, відсилання від одного листа до іншого - усе це своєрідні “скрепи”, що не дають змоги збірці розпастися на окремі положення й розмисли. Єднальною субстанцією постає й сама адресантка, яка організовує тексти в цілісний “сюжет”, що спричинює рефлексію як складник досвіду. Зв'язність тексту забезпечується й лексико-стилістичною структурою як макротексту Листів з Києва, так і складників мікротексту. Окремі листи (напр., від 28 червня 1990 р., від 9 грудня 1991 р.) можуть претендувати на певні смислові центри через важливу акцентованість подій і глибину їхнього переосмислення, однак це можна зробити тільки з певною долею умовності.

Звісно, кожен окремий лист має свою комунікативну стратегію - описати події в Україні на підступах до їі незалежності, власні враження про них, дати оцінку фактам і ситуаціям, поміркувати про можливі наслідки, поділитися роздумами й розмислами про ймовірний розвиток та варіанти змін ситуації в країні. Однак із сукупності всіх листів-есеїв чітко вимальовується комунікативна гранд-стратегія: показати чинники й важелі перетворення свідомості людиниінтелігента в добу змін. Так, адресант листів, написаних із коліс, 3 аполітичного суб'єкта перетворюється на небайдужу особистість, готову серцем і розумом прийняти демократичні зміни в країні й переродження свідомості, адже жити за старої системи й колишніх обставин просто не може. Відтак дозволимо собі не погодитися з О. Забужко, яка вважає, що голос з Листів з Києва “доносив страх"2. Не страх, а його подолання в непростих умовах оновлення й перетворень становить суть комунікативної стратегії адресантки: якщо з перших сторінок лунала думка про те, що "немає великих надій”з, то на останніх читаємо “назад дороги нема"4.

Нараторка з листів постає справжнім хронікером доби, що заслуговує найвищої оцінки. І хоча події осмислюються через свідомість адресанта, все ж таки подієве начало твору викликає особливо схвального відгуку. Події, явища, ситуації описані детально, наочно, конкретно. Усі вони мають свій “сюжет” чи “фабулу”, послідовність епізодів і тем розповіді має принциповий характер. Розповідь провокує ті чи ті міркування, які напряму пов'язані з тим, про що йдеться перед цим. Нараторка переповідає те, що відбувається не тільки в Києві, а й в інших містах і містечках України - Тернополі, Львові тощо. Цілком очевидно, що первинна комунікативна стратегія, наявна в Листах - наочність і деталізованість, акцентуація нюансів, подробиць. С. Павличко надає перевагу тонкощам, потужним своєю очевидністю: „,28 червня. В райцентрі (маленькому містечку Підволочиськ) на флатшточі висить синьо-жовтий прапор. Навколо з усіх боків на ие «неподобство» дивляться Леніни - з пам'ятника коло райкому партї - найбільшого будинку в місті, з барельєфів, кошмарних стендів, Дощуок пошани. Я їх нарахувала 5. Якось я дуже почала помічати ичих Ленінів. Стало менше лозуніів, але всюди очі ріжуть Леніни. Потворні, не подібні на себе, витворені провіниійними богомазами, замальовані блискучою золотою фарбою, білі гіпсові, пінопластові, порожні всередині, як уся наша ідеологія"”.

\footnotetext{
${ }^{2}$ О. Забужко, Репортаж з 2000-го року, Київ, 2000, с. 73.

${ }^{3}$ С. Павличко, Листи з Києва, Київ, 2000, с. 11.

${ }^{4}$ Там само, с. 122.

${ }^{5}$ Там само, с. 36.
} 
$\mathrm{y}$ наведеному уривку наочно використано прийом контрасту в акценті на певних деталях: пам'ятники Леніну й синьо-жовтий прапор як “зустріч” нової та старої ідеологій.

Дієгезис листів С. Павличко вирізняється гостротою референції, часто основою епістолярних творів стають “гарячі" повідомлення, написані одразу після побаченого й пережитого, відтак описані події нагадують точні, виражальні рядки міцно скріпленої хроніки: „, листопада. Наш театр тепер живе без цензури і естетичних обмежень з боку чиновників з Міністерства культури. Тому він став розкованим, авантардним, експериментальним. Правда, він часто переживає ті експерименти, які в західному театрі минули двадиять років тому. Правда й те, що до театру майже ніхто не ходить. Хіба крайні естети і театрали... Останніми днями я побачила дві справді добрі вистави: Петера Вайса «Марат - Сад»... «О-О-И» (Чорнобиль) Андрія Жолдака... Неясно тільки, де більше театру - в театрі чи в реальному житті" .

Єдине, чого немає в репрезентованих подіях нараторки, так це лаконічності, адже вона пише не замітки, а листи, що дуже наближаються до есе, а відтак годі шукати в іiї творах вивіреної протяжності й ритміки повідомлення. Натомість мають місце міркування, різного роду відступи, що властиво саме цій дискурсивній практиці, ментативній за своєю суттю. Можливо, саме тому сама нараторка не завжди називає свої твори листами, подекуди іменуючи їх просто “інформацією”, інколи - "писаниною”, а то й, у дусі Ф. Достоєвського, “записками з мертвого дому".

Ментатив Листів з Києва формується особистісним характером сприйняття й способом подання інформації, різним ступенем суб'єктивації розповіді, певною долею відвертості оповідача, що стає мислителем, наближеним до автора; індивідуальним стилем письма, етюдністю вирішення тем, прагненням референта до самовираження, вільною, розкутою композицією, невимушеністю розповіді. Функціонально-прагматичний потенціал епістоляріїв С. Павличко вибудовується на наративі, що перетворюється на ментатив як його природне доповнення й продовження.

Попри той факт, що лист $є$ твором виключно особистісним, інтимним, усетаки рушієм сюжету й думки в ньому автор не є: первісний автор твору в тексті не виявляє себе, адже перебуває в стані своєрідного мовчання, ставиться до твору опосередковано і $є$ феноменом позаестетичної величини - позазнаходження7. Первинний автор стає відносно власного твору трансцендентальним, але перебуває до нього в іманентній позиції, зокрема у створених образах героїв і наратора, щодо есе - героїв і наратора, котрий перетворюються на мислителя (екзогітатора).

У Листах з Києва чітко виокремлюються такі основні види нараторів: автодієгетичний і гомодієгетичний ${ }^{8}$. Гомодієгетичний може в окремих випадках перетворюватися на гетеродієгетичного (у розповідях про події з парламенту, мітингів, зустрічей). Автодієгетичний наратор (мовний показник - використання займенника першої особи однини) $є$ головним героєм в епістолярному наративі й розповідає про події, безпосереднім учасником яких була сама адресантка. Напр., його можна зустріти в листах про ходу в колоні, святкування ювілею професора, який усе життя писав про соцреалізм, або відвідування голодуючих

${ }^{6}$ Там само, с. 102.

${ }^{7}$ М. Бахтин, Автор и герой в эстетической деятельности. Проблема автора, [в:] Електронний ресурс: http://mmbakhtin.narod.ru/probl.html (20.01.2018).

${ }^{8}$ В. Шмид, Нарратология, Москва 2003, с. 47. 
студентів на Майдані Незалежності. У таких листах оповідь часто побудовано на основі персонажного мовлення, описані події представляються як достовірні, такі, що мали місце в реальному житті головного персонажа-адресанта. Використання займенника "я" створює атмосферу довірливості та інтимності, що $\epsilon$ природньою властивістю твору-листа. Автодієгетична нарація збагачується елементами психоаналізу, описами емоційного стану адресантки, міркуваннями та ін., що підкреслюють суб'єктивність семантики есею-епістоли, напр., в описах стану безнадії, безпорадності страху перед майбутнім у період розвалу СРСР. Гомодієгетичний наратор у листах функціонує як персонаж-оповідач у ситуаціях та подіях, про які він оповідає, або ж він говорить про події, почуті від когось - у збірці основним джерелом інформації виступає батько літераторки. В обох оповідних формах дія розгортається з опертям на особистісний, суб'єктивний план або названого в тексті оповідача, що має певне ставлення до подій, не байдужий до відтворених перипетій, або однісї з головних дійових осіб, яка виступає одночасно і персонажем, і оповідачем. Ці дві форми нарації орієнтовані на моделювання різноманітних комунікативно-мовленнєвих ситуацій, доступних для відтворення в листі: портретування (,,Язов... чомусь нагадав мені генералів Салтикова-Щедріна - дебелий, з якоюсь космічною зачіскою - невеликий жсмут волосся, тобто його рештки зачесані ззаду наперед на лисину, наче завеликі погони з непропориійно великими зірками"'), характеризації (,„Степан Хмара... - запальний, лютий, навіжений, вибуховий, невротичний, безкомпромісний”'10), презентації (,, Вистава йде в холі одного з київських інститутів, який має вигляд звалки сміття, помийної ями. Настрій можна окреслити як чорний гумор "Il), ідентифікації (,, В намій групі були в основному молодi поети, різного роду авангардисти і літературні хулігани... Для мене вони вже давно стали значно приємнішим товариством, ніж мої набундючені академічні колеги" ${ }^{22}$ ), описів з метою підкреслити особистісну (зовнішню і внутрішню) індивідуальність (,, відчуваю настрій навколо себе, водночас дратуюся тими, котрим усе байдуже"'13), опис з метою надати позитивну чи негативну оцінку, зіставлення (,, я усвідомлюю, що робиться «велика» історія, але вона все більше нагадує мені шторм у північних океанах, котрий кидає один на одного величезні айсберги"14), відсторонення (, останнім часом все менше стежу за перипетіями політичного життя"'15) тощо.

Обидва види я-нарації, наявні в тексті, дуже близькі самій авторці, яка не озирається на "іконостаси”, приписи, усталені оцінки, iї погляд індивідуалізований, незашорений. У кожному листі нараторка постає щоразу в новій ролі: то прискіпливого й допитливого свідка подій та їхнього фіксатора, хронікера (,,з мене так само не вийде якогось серйозного хронікера на довший час"'เ6), то науковця (, ти можеш спитати, чому мені - естетові - так перейматися компартійними з'іздами? Причина проста - вираховую шанси на «nравий» coup d'etat"' ), то громадянина (,, було повно таких, як $i$ я,... кому ще

\footnotetext{
${ }^{9}$ С. Павличко, Листи з Кисва, Київ 2000, с. 113.

${ }^{10}$ Там само, с. 104.

${ }^{11}$ Там само, с. 102.

12 Там само, с. 76.

13 Там само, с. 122.

${ }^{14}$ Там само, с. 121.

15 Там само, с. 126.

${ }^{16}$ Там само, c. 145 .

17 Tам само, c. 41.
} 
півроку тому всіляка начіональна ідея здавалась досить чужою"18), то жінкою, матір'ю (,,Моя найбільша проблема - пояснити Богдані, якій три з половиною роки, чому немає иукру, бананів, риби, чому в магазині іграмок немає іграшок, а в магазині конфет немає конфет "'19), то донькою відомого поета, опозиціонера Павличка, хоч цим авторка зовсім не хизується, адже навіть іменує його виключно Д. П. і жодного разу не називає “мій батько” (, У самого Д. П. настрій і дедалі чорний"20).

Але $є$ дещо, що ріднить усі без винятку ролі: уживання образних конструкцій свідчить про небайдуже ставлення нараторки до досліджуваних об'єктів, що, зрештою, зближує ії й читача, як зближують окремих людей спільні інтереси. $€$ й інші засоби зменшення інтерактивної дистанції між наратором і читачем: психологічні одкровення, інтимізація, ліризація тощо. Так, емоційне ставлення нараторки до ідеї, омріяної і необхідної на цьому етапі розвитку незалежності, прочитується буквально в кожному рядкові твору. Емоційно-психологічний виклад $є$ одним із засобів точно зорієнтувати текст на реципієнта: авторка адресує твір “своєму" читачеві, а в нього виникає враження, що автор "свій”, того самого кола, тих самих поглядів, що й читач, і йому варто довіряти. У такий спосіб у спілкуванні через текст налагоджується теплий, неформальний контакт наратора із читачем. I це попри той факт, що Листи не призначалися широкій аудиторії, а були спрямовані професору Богданові Кравченку.

На нашу думку, дискурс самопрезентації наратора в есе-листі репрезенований двома рівнями: по-перше, рівнем соціальної категоризації, по-друге, рівнем психологічної характеризації. Перший рівень обмежує адресантку як соціального об'єкта. Так, наратор у Листах є обсерватором подій крізь призму бачення науковця-літературознавця, філолога, перекладача, автора статей, монографій, резенцій - про це більшою мірою йдеться в другій половині книги, коли обережно розповідається про становлення феміністичної критики у вітчизняному літературознавстві. Він самоідентифікується через співвіднесеність з постатями, персонажами, творами, науковими заходами насамперед. Другий рівень принципово безмежний: тут оголюється свідомість того, на якого покладена місія описувати, обсервувати й давати оцінку, іншими словами, розкривати чинники існування особистості як такої. На нашу думку, саме цей другий рівень самопрезентації наратора стає "трампліном" до формування іншого зрізу листів-есеїв - ментативного, адже самопроектування особистості неодмінно провокує низку розмислів і роздумів, задає вектор розмірковуванням як процесу глибокого розуміння в стані вищої пробудженості, як-от у такому фрагменті: „Ми всі зрозуміли, що як далеко ще нам до демократії, до свободи слова, до свободи взагалі. А до добробуту? Це взагалі щось неймовірне! Печать иього розчарування лягла тінню на ціле наше життя, на кожну розмову, вона в жестах i в міміиі людей, воно - в мені, я його відчуваю просто біологічно, як те, що весь час $\epsilon$, від чого неможливо позбутися..." "21.

Роздуми про абсурдність радянської системи, історичну необхідність української незалежності, вічне й проминальне, ціну людського життя, невмирущість людського в людині є повною мірою продовженням наративу, своєрідним поверненням подумки до себе самого як окремого об'єкта. Актуальність роздумів, зумовлених епістолярним жанром, оцінюється в співвіднесенос-

\footnotetext{
${ }^{18}$ Там само, с. 72.

19 Там само, с. 82 .

${ }^{20}$ Там само, с. 123.

${ }^{21}$ Там само, с. 131.
} 
ті із часом відтворених подій, історичної епохи їх здійснення й досить часто у співмірності із загальнолюдськими цінностями. Ментативний складник листів 1990-1991 р.p. є згустком вражень інтелігента-науковця тої доби, “згорнутим конспектом” його почуттів. Згодом у майбутніх наукових і перекладацьких творах, інтерв'ю С. Павличко він розгорнеться складними філософськопубліцистичними роздумами про людське буття й суперечливе українське сьогодення, офарблене образністю художнього слова і точністю наукового, подане в окремих публіцистичних і наукових виступах. Однак на рівні листа вже цілком природним було звернення до слова-роздуму для того, щоб дати лад власним думкам, зрозуміти ціну людського життя, визначити своє місце в історичних подіях однієї з найдраматичніших епох в історії України.

На нашу думку, основна комунікативна стратегія ментативу в листах застосування. За лінгвістичною класифікацією ментативів Н. Максимової, „«застосування» полягає не просто в новому формально рематичному кроці, а у лексико-семантичній співвіднесеності двох рем, змістовній глибині кроку не так фактологічного, як, відповідно до логіко-змістовного субстрату текстументативу, власне ментального, що полягає в новому похідному статусі, перетворюваності змісту реми-«чужого»" 22 . Вочевидь, виходячи із цього, літературознавий акцент варто зробити на тому, як та чи та важлива інформація, викладена у причиново-наслідковій послідовності (“чуже”), провокує певний характер міркувань (“своє”) як можливість пропущення крізь власну шкалу життєвих цінностей і пріоритетів.

У Листах, насамперед 1991 р., ментальна референція виникає не лише в дискурсі зображення, але й у зображуваному дискурсі. Адресантка дедалі більше пише про себе, а не тільки описує події, адресат іiі дедалі активніше сприймає як опінієтворчу особистість, адже дедалі іiі потенціал у цьому сенсі зростає. Самооцінка, погляд на оточення - нове й старе, міркування про людей, майбутнє країни, завтрашнє науки й мистецтва в добу змін усе більше й більше доповнюють хронопис, заради якого, власне, і зав'язувалося листування. Ментальні події, які переживає адресантка, зміна станів концентрують основний комунікативний інтерес, підсилюючи тим самим відповідний тип референції. Напр., у листі від 1 лютого: „Сьогодні мав бути особливий день. Початок офіційного напіввійськового стану, проти якого вже офіційно протестували 6 республік... Але в Києві, здається, тихо... В останні дні вдарив мороз. На вулииі сонце, вітер $i-20$. Мої фантазї мають останнім часом якісь сюрреалістичні виміри, і тому я сиджу і думаю, чи холодно в танку в таку погоду" 23.

Ментатив С. Павличко складають спершу невеликі пояснення, що переростають у міркування, котрі зазвичай продовжують описи перипетій у Києві часів пізньої перебудови чи акцій на вулицях, в Інституті літератури тощо. Однак дедалі ментативне начало в листах активізується: міркування стають розлогішими, коментування й оцінки доповнюються узагальненнями, прогностичні сентенції все більше увиразнюються й посилюються. Свої роздуми (рефлексія, особливе посилення думки, внутрішнє почуття, підгрунтям якого є інтелект і свідомий намір) і міркування (встановлення каузального зв'язку між явищами реального й мислимого світу) нараторка, здебільшого, оформлює як індуктивні: приклади дають підстави для узагальнень і доказів, а вони, відповідно, уможлив-

22 Н. Максимова, Понимание в диалоге: текстовые модели ментатива, Новосибирск 2012, [в:] Электронный ресурс: https://www.metod-kopilka.ru/tekstovaya_kultura_modeli_ rassuzhdeniya_v_russkom_tekste._monografiya-26564.htm (12.01.2018).

${ }^{23}$ С. Павличко, Лйсти з Києва, Київ 2000, с. 142. 
люють тези. Напр.: „Ми в розвитку револючійних прочесів відстаємо від Львова десь місяиів на десять, отже, за логікою історії, десь весною і в нас, сподіваюсь, стане одним Леніним менше. На Хрещатику, як ти пам'ятаєщ, мабуть, їх стоїть аж два. Принаймні крок до того вже міськрада зробила: площу Жовтневої революиії перейменовано днями в Майдан Незалежності. Незалежнос$m i$, правда, ще нема, але принаймні площа вже $\epsilon^{\prime 24}$. У цьому невеликому фрагменті міркування не містить концептуальної інформації, а розкриває істинність вихідної тези - про політичну відсталість Києва порівняно зі Львовом. Аргументативність уривка більшою мірою емоційна, аніж логічна. Тим не менш, вона прозора й цілком зрозуміла, навіть у такому оксюморонному варіанті. Часто в ментативі С. Павличко віднаходимо ті чи ті визначення, більшою мірою метафоричні, що розкриваються, розвиваються саме в поясненні: „Тепер знаю, що таке гласність. Це - коли дізнаєшся про переворот не тоді, коли бачиш на вулииі танки, а коли читаєш про нього за два тижні наперед в газетах" 25.

Міркування в листах, звісно, не можуть претендувати на статус глибоких умовиводів, що зустрічаються в наукових публікаціях: логіко-композиційний аспект їхньої побудови послаблений, переважає стилістично-риторичний план вираження думки. Часто вона обігрується з різних боків, напр., із погляду політикуму й пересічних громадян, відтак окреслюються різні грані однієї й тієї позиції, у звичному відкриваються нові аспекти, виникають свіжі горизонти осмислення. Але тим цінніша роль цих осмислень у листах, що, власне, завдяки ментативному складникові й набувають ознак есею, стають цікавими не тільки тим, хто переживав ті ж події, описані в збірці свого часу, а й тим, хто про них дізнався тільки 3 підручників і може оцінити їхню інтерпретацію ззовні. Ментативні вкраплення наповнені питаннями пошукового характеру, націлені на відновлення власного досвіду, осмислення, узагальнення. Репродуктивні питання зведено до мінімуму - це є підставою для активізації мовленнєвої діяльності нараторки. Ідіостиль Листів складають розлогі синтаксичні конструкції, ускладнені речення, вставні слова, що зв’язують абзаци, питання “Чому?”, які порушуються одразу після чітко прописаної тези. Напр.: „Інша тема, яка приводить мене в такий самий стан повного жаху, - ие Чорнобиль. Я вже давно при кожній згадиі про нього по телевізору просто переключаю на іншу програму... Чому? Тому, що не можу бачити, просто психічно не витримую. Найгірше, що Чорнобиль нічому не навчив, і система, яка його породила, досі жива, $i$ люди, котрі ії захищали, досі ії захищають "26. В інших випадках зустрічаємо цілий каскад риторичних питань, що в такий спосіб задають вектор розвитку думки: „,Генсек не припускає можливості розпаду Союзу... Чи ие сліпота? Чи бажання зупинити історію? Зрозуміти важко, але така позиція лякає. А якщо в них вийде? Я, так само, як і більшість людей мого оточення, сприймаю те, що зараз відбувається, як останній шанс для України" 27 . Ще одна наочна прикмета ідіостилю в ментативі С. Павличко - побудова власної думки слідом за наведеною цитатою-думкою, що або захищається як теза, або спростовується: „Показують по телевізору наших обездолених бабусь з молоком чи соками $i$ західними продуктами. В якійсь «вашій» газеті я прочитала, що захід робить ие великою мірою, щоб втримати Горбачова, тут до иієї допомоги ставляться порізному, багато хто з осудом. Алкоголікові скільки не давай пити, йому все одно

\footnotetext{
${ }^{24}$ Там само, с. 62-63.

${ }^{25}$ Там само, с. 135.

${ }^{26}$ Там само, с. 110-111.

${ }^{27}$ Там само, с. 39.
} 
не стане. Якщзо система недолуга, ніякі дарунки і кредити не допоможуть" 28. Як можна судити з наведеного фрагменту, у міркуваннях велика роль відводиться розгорнутій метафорі, що побудована на асоціаціях за принципом схожості / несхожості. Саме метафора - надпотужний засіб образності, що стає частиною й ментативного блоку листів-есеїв, зокрема: „демократія на сьогодні скінчилася”, „стало менше лозунгів, але всюди очі ріжуть Леніни”, „ненависть до влади прогресує. Голодовка розростається".

Попри підкреслено авторський в окремих випадках емоційно забарвлений характер міркувань Листів з Києва, усе-таки зазначимо, що вони не хаотичні, а взаємообумовлені й взаємопов'язані, цілком співвіднесені з наративною частиною. Часто цей зв'язок асоціативний, однак це аж ніяк не позначається на системності тексту, що є цілісним й когерентним мовним утворенням.

Отже, комунікативна природа Листів з Києва С. Павличко є наративноментативною. Оповідь задає напрям ментативу, тобто переростає в міркування, наратор перетворюється на мислителя. Наратив і ментатив стають важливими складниками один одного, утворюючи цілісність. Така структура відкриває нові можливості есе-листа як дискурсивної практики з огляду на комунікативні стратегії у творчості митців сучасності, що варті подальшого наукового осмислення.

\section{Список використаної літератури}

Бахтин М., Автор и герой в эстетической деятельности. Проблема автора, [в:] Електронный ресурс: http://mmbakhtin.narod.ru/probl.html (20.01.2018).

Забужко О., Репортаж з 2000-го року, Київ 2000.

Максимова Н., Понимание в диалоге: текстовые модели ментатива, моногр., Новосибирск 2012, [в:] Электронный ресурс: https://www.metod-kopilka.ru/tekstovaya_ kultura_modeli_rassuzhdeniya_v_russkom_tekste._monografiya-26564.htm (12.01.2018).

Павличко С., Листи з Києва, Київ 2000.

Шмид В., Нарратология, Москва 2003.

\section{Spysok vykorystanoi literatury [References]}

Bahtin M., Avtor i geroj ve 'steticheskoj deyatel'nosti. Problema avtora [Author and Hero in Ethetic Activity. The Problem of the Author], [v:] E'lektronnyj resurs: http://mmbakhtin. narod.ru/probl.html (20.01.2018).

Zabuzhko O., Reportazh z 2000-ho roku [Report from 2000], Kyiv 2000.

Maksimova N., Ponimanie v dialoge: tekstovye modeli mentativa, monogr. [Understanding in Dialogue: Text Models of Mentative], Novosibirsk 2012, [v:] E`lektronnyj resurs: https:// www.metod-kopilka.ru/tekstovaya_kultura_modeli_rassuzhdeniya_v_russkom_tekste. monografiya-26564.htm (12.01.2018).

Pavlychko S., Lysty z Kyieva [Letters from Kyiv], Kyiv 2000.

Shmid V., Narratologija [Narratology], Moskva 2003.

${ }^{28}$ Там само, с. 126. 